\section{To: (Receiving Organization)}

Distribution

5. Proj./Prog./Dept./Div.:

HANDI 2000 INTEGRATION

8. Originator Remarks:

FOR RELEASE

11. Receiver Remarks:
3. From: (Originating Organization)

dion Systems

6. Design Authority/Design AgentCog. Engr.:

DAWN E. ADAMS
4. Related EDT No::

$\mathrm{N} / \mathrm{A}$

7. Purchase Order No.:

$\mathrm{N} / \mathrm{A}$

9. Equip./Component No.:

N/A

10. System/B/dg.JFacility:

$\mathrm{N} / \mathrm{A}$

12. Major Assm. Dwg. No.:

N $/ A$

13. Permit/Permit Application No.:

$\mathrm{N} / \mathrm{A}$

14. Required Response Date:

N/A

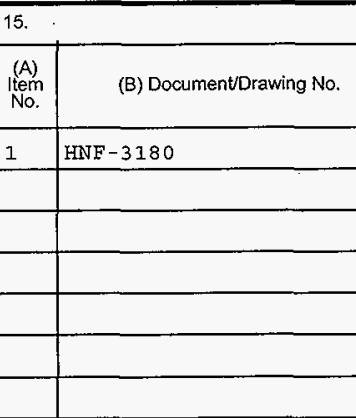

16.

DATA TRANSMITTED

$\begin{array}{lll}\text { (C) Sheet } & \text { (D) Rev. } & \text { (E) Title or Description of Data Transmitted } \\ \text { No. } & \text { No. }\end{array}$

(F)

(G)

(H)

Approval Reason

Origi-

nator

Desig-
nator $\begin{gathered}\text { for Trans- Dittal } \\ \text { mispo- }\end{gathered}$

\begin{tabular}{|l|l|l|}
\hline AII & REV 0 & OPERATTONS PERFORMANCE FOR \\
& & HANDI 2000 BUSINESS \\
\hline & & MANAGEMENT SYSTEM \\
\hline
\end{tabular}

KEY

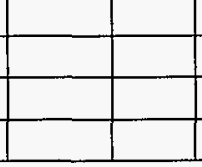

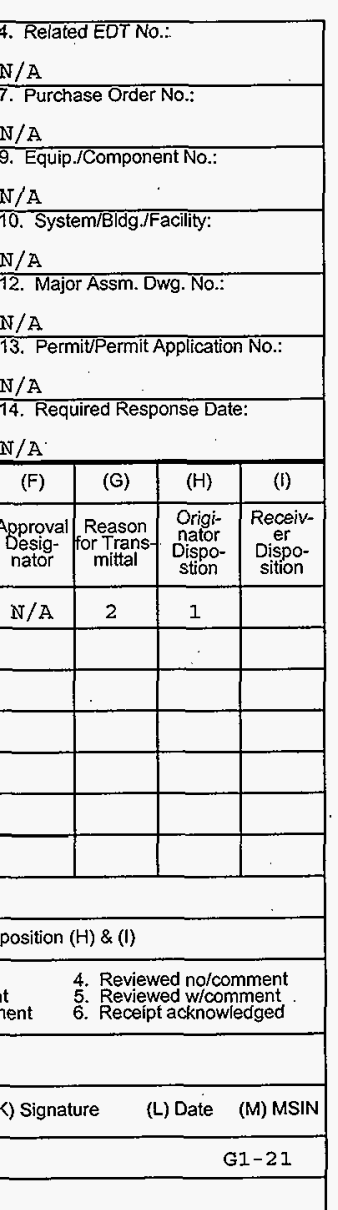

\begin{tabular}{|c|l|}
\hline Approval Designator (F) & \\
\hline E, S, O.D OR N/A & 1. Approval \\
(See WHC-CM-3-5, & 2. Release \\
Sec. 12.7) & 3. Information \\
\hline
\end{tabular}

17.

\begin{tabular}{|c|c|l|}
\hline $\begin{array}{c}\text { Rea } \\
\text { son }\end{array}$ & $\begin{array}{c}(\mathrm{H}) \\
\text { Disp. }\end{array}$ & (J) Name \\
\hline 2 & 1 & Design Authority DAWN \\
\hline & & Design Agent \\
\hline & & Cog. Eng. \\
\hline & & Cog. Mgr. \\
\hline & & OA \\
\hline & & Safety \\
\hline 18. & & Env. \\
\hline A. & \\
Signature of EDT \\
Originator
\end{tabular}

(K) Signature

Reason for Transmittal (G)
4. Review
5. Post-Review
6. Dist. (Receipt Acknow. Required)

E. ADAMS

GI-21 3
Disposition $(\mathrm{H})$ \& (I)

\section{Approved}

2. Approved w/comment

3. Disapproved w/comment
4. Reviewed no/comment

5. Reviewed w/comment

6. Receipt acknowledged SIGNATUREJDISTRIBUTION

(See Approval Designator for required signatures)
(L) Date
(J) Name
(K) Signature
(L) Date
(M) MSIN

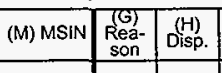

DIANE WILSON

G1-21

DIANE WILSON

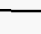




\title{
OPERATIONS PERFORMANCE FOR HANDI 2000 BUSINESS MANAGEMENT SYSTEM
}

\author{
Dawn F. Adams, FDH \\ 2355 Stevens, MSIN G1-21 \\ Richland, WA 99352 \\ U.S. Department of Energy Contract DE-AC06-96RL13200

$\begin{array}{lll}\text { EDT/ECN: } & 625365 & \text { UC: } 900 \\ \text { Org Code: } & \text { SL610000 } & \text { Charge Code: HANE6800 } \\ \text { B\&R Code: } & \text { EW7001000 } & \text { Total Pages: } 6\end{array}$

Key Words: HANDI 2000, BUSINESS MANAGEMENT, OPERATIONS PERFORMANCE, $\mathrm{H} 2 \mathrm{~K}$, BMS, PEOPLESOFT, PASSPORT

Abstract: Performance management consists of performance monitoring and tuning as well as longer-term capacity planning. The objective of Operations Performance Management Plan is to assure that performance and response time commitments are satisfied. This is achieved through daily monitoring and capacity planning using workload forecasting and historical trends. The ORMP becomes effective as of this document's acceptance. It will provide guidance through implementation efforts. .

TRADEMARK DISCLAIMER. Reference herein to any specific commercial product, process, or service by trade name, trademark, manufacturer, or otherwise, does not necessarily constitute or imply its endorsement, recommendation, or favoring by the United States Government or any agency thereof or its contractors or subcontractors.

Printed in the United States of America. To obtain copies of this document, contact: Document Control Services, P.O. Box 950, Mailstop H6-08, Richland WA 99352, Phone (509) 372-2420; Fax (509) 376-4989.

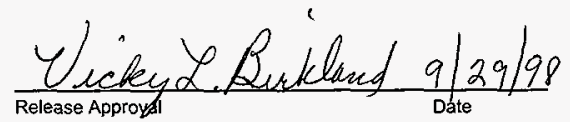

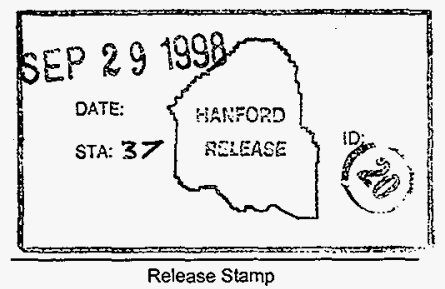

Release Stamp 


\section{OPERATIONS PERFORMANCE MANAGEMENT PLAN \\ FOR}

HANDI 2000

BUSINESS MANAGEMENT SYSTEM

Prepared by: Judy Springer, LMSI Computer Systems Management Manager

Sandra Evosevich, LMSI Software Engineer

Prepared for: Fluor Daniel Hanford

Approved by:
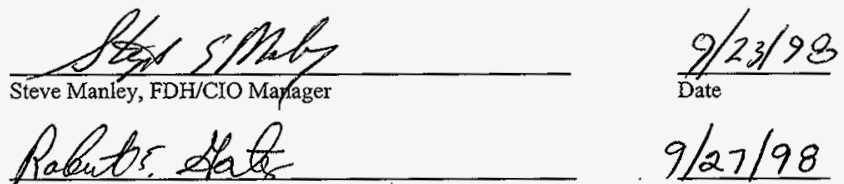

Robert E. Gates, H2K Project Director
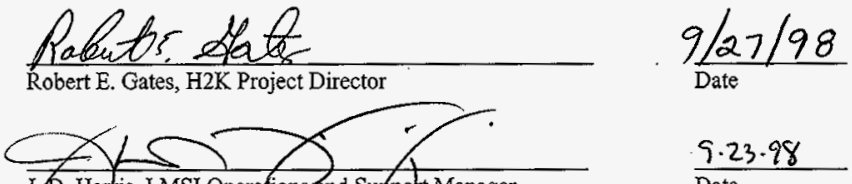

JP. Hantis, LMSI Operationsand Suppgrt Manager

9.23 .98

Date

\section{Nele $\{M \times$ slear}

Dale E. McElroy, LMSI Telecoffmunications and Network Engineering Manager

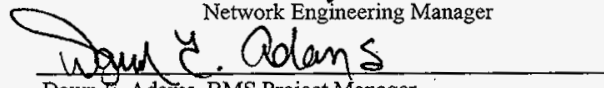

Dawn E. Adañs, BMS Project Manager

$9 \longdiv { 2 4 / 9 8 }$

Date

$9 / 5 / 98$

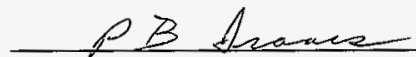

Phillip B. (Brian) Isaacs, LMSI Project Manager

$\frac{9 / 3 / 98}{\text { Date }}$

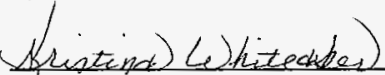

$\frac{9 / 17 / 98}{\text { Date }}$ 


\section{TABLE OF CONTENTS}

\begin{tabular}{|c|c|}
\hline 1 & INTRODUCTION \\
\hline 1.1 & OVERVIEW ......... \\
\hline .2 & PURPOSE. \\
\hline 3 & 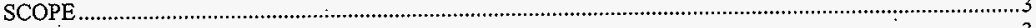 \\
\hline 4 & ACRONYM DEFI \\
\hline & REFERENCES ..... \\
\hline & PERFORMANCE MA \\
\hline & PLANNING ..... \\
\hline & (n) \\
\hline & MEASUREMENT ........................... \\
\hline & (1) \\
\hline & TUNING ................................................ \\
\hline & ............. \\
\hline & , \\
\hline & 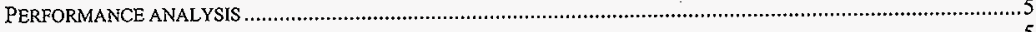 \\
\hline & $2 \mathrm{TCS}$ \\
\hline
\end{tabular}

\section{TRADEMARKS}

PeopleSoft (PS) is a trademark of PeopleSoft Corporation.

HP is a trademark of Hewlett Packard.

HP Service Guard is a trademark of Hewlett Packard.

Oracle is a trademark of Oracle Corporation.

UNIX is a trademark licensed exclusively through $\mathrm{X} /$ Open Co. Ltd.

Microsoft NT is a trademark of Microsoft Corporation. 


\section{INTRODUCTION}

\subsection{OVERVIEW}

The Hanford Data Integration 2000 (HANDI 2000) Project will result in an integrated and comprehensive set of functional applications containing core information necessary to support the Project Hanford Management Contract (PHMC). It is based on the Commercial-Off-The-Shelf (COTS) product solution with commercially proven business processes. The system will reduce the number of legacy systems maintained today and absorb key systems identified that have Year 2000 issues. This includes systems that support finance, supply, chemical management/Material Safety Data Sheet (MSDS), human resources and payroll activities on the Hanford Site. The PassPort (PP) software is an integrated application for Accounts Payable, Contract Management, Inventory Management, Purchasing and MSDS. The PeopleSoft (PS) software is an integrated application for General Ledger, Project Costing, Human Resources, Payroll, Benefits, and Training. The implementation of this set of products, as the first deliverable of the HANDI 2000 Project, is referred to as Business Management System (BMS) and MSDS.

\subsection{PURPOSE}

Performance management consists of performance monitoring and tuning as well as longer-term capacity planning. The objective of Operations Performance Management Plan (OPMP) is to assure that performance and response time commitments are satisfied. This is achieved through daily monitoring and capacity planning using workload forecasting and historical trends. This OPMP becomes effective as of this document's acceptance. It will provide guidance through implementation efforts. As a "living document", it will support the operation and maintenance of the HANDI 2000 systems.

\section{$1.3 \quad$ SCOPE}

The OPMP addresses the major areas of performance management for planning, monitoring, measurement, reporting, capacity planning, and system tuning.

\subsection{ACRONYM DEFINITIONS}

\begin{tabular}{|l|l|}
\hline \multicolumn{1}{|c|}{ Acronym } & \multicolumn{1}{c|}{ Definition } \\
\hline BMS & Business Management System \\
\hline COTS & Commercial off the Shelf \\
\hline FDH & Fluor Daniel Hanford \\
\hline HANDI 2000 & Hanford Data Integration (Year 2000 compliant) \\
\hline HLAN & Hanford Local Area Network \\
\hline HP & Hewlett Packard \\
\hline LMSI & Lockheed Martin Services, Incorporated \\
\hline MSDS & Material Safety Data Sheet \\
\hline OPMP & Operations Performance Management Plan \\
\hline PHMC & Project Management Hanford Contract \\
\hline PP & PassPort \\
\hline PS & PeopleSoft \\
\hline & \\
\hline
\end{tabular}

\subsection{REFERENCES}

HNF-2858

Backup and Recovery Plan

HNF-2859

Disaster Recovery Plan 


\section{PERFORMANCE MANAGEMENT}

Performance management involves real-time monitoring, trending, automated preventive scripts for error detection and recovery, and procedures for recovery. The resources to be managed are the servers, databases, applications, and network. The areas reported are availability, utilization, response time, and workload volume. The BMS and Chemical Management'MSDS production implementation will be complete by October 01, 1998. The server environment will be comprised of two types of platforms. The PassPort Supply and the PeopleSoft Financials will reside on UNIX servers and the PeopleSoft Human Resources and Payroll will reside on Microsoft NT servers.

Performance management will be proactive and preventive as much as possible. This includes notification via paging and messaging when system resource thresholds are exceeded or when systems services are unavailable. Performance issues will be resolved as soon as they are identified. Examples of thresholds would be disk and table space alarms. Automated procedures will be used to assure key components are operational. Messages can be trapped and corrective actions programmed reducing human intervention. The Hewlett Packard (HP) Service Guard high availability configuration will be utilized to assure the operation of the production environment.

\subsection{PLANNING}

Identify and plan for the following items:

- Availability

- Reliability

- Response time

- Workload requirements

\subsection{MONITORING}

- Production support of automated tools and monitoring availability

- Response time

- Utilization

- Workload volume trends

\subsection{MEASUREMENT}

- Analyze performance data

- Create management reports

\subsection{CAPACITY PLANNING}

- Actual and projected utilization

- Identify constraints

- Recommend changes

\section{$2.5 \quad$ TUNING}

- Optimize resources

- Recommend changes to optimize performance 


\section{TOOLS}

Operation and Support will use several vendor-automated tools and production scripts to provide performance management services. The automated vendor tools will be used for troubleshooting performance problems, monitoring, and automated corrective actions. The tools will provide dynamic on-line alerts, passive status monitoring, and periodic report generation.

\subsection{VENDOR AUTOMATED TOOLS}

- Computer Associates Unicenter modules - event and performance management, Oracle monitoring.

- HP Open View, Glance+, JFS

- EMC2 Open Symmetrix Manager

\subsection{PERFORMANCE ANALYSIS}

Performance analysis must be conducted to evaluate the impact of requested changes to application codes, hardware, operating system, database, planned workload, and system configuration. Operation and Support will support benchmarks and special application testing. Technical staff will evaluate new technology that can improve system performance.

\subsection{PERFORMANCE METRICS}

Operations and Support provides Chief Information Officer (CIO) Office with monthly metrics for all HANDr 2000 systems. The BMS/Chemical Management MSDS systems will be included in the Operation and Support metrics report. The metrics will be based on service level agreements. Daily performance status will be included in the daily Morning Report. The Morning Report will be used to report performance problems and resolutions to those problems. Performance problems have the attention of both Operational and Business management. The On-Call Procedures will be used to assure timely recovery of a system or service. Reference HNF-2858, Backup and Recovery Plan and HNF-2859, Disaster Recovery Plan 